\title{
Stellate cells in livers of dogs with portal vein hypoperfusion
}

\author{
MAŁGORZATA SOBCZAK-FILIPIAK, JÓZEF SZAREK*, MICHAŁ CZOPOWICZ**, \\ MAREK GALANTY***, IZABELLA DOLKA, PIOTR TRĘBACZ ${ }^{* * *}$, JAN FRYMUS ${ }^{* * *}$, \\ ROMAN LECHOWSKI***
}

\begin{abstract}
Department of Pathology and Veterinary Diagnostics, **Laboratory of Veterinary Epidemiology and Economics, ***Department of Small Animal Diseases with Clinic, Faculty of Veterinary Medicine, Warsaw University of Life Sciences, Nowoursynowska St. 159C, 02-776 Warsaw, Poland

*Department of Pathophysiology, Forensic Veterinary Medicine and Administration, University of Warmia and Mazury in Olsztyn, Oczapowskiego St. 13, 10-719 Olsztyn, Poland
\end{abstract}

Sobczak-Filipiak M., Szarek J., Czopowicz M., Galanty M., Dolka I., Trębacz P., Frymus J., Lechowski R. Stellate cells in livers of dogs with portal vein hypoperfusion

\section{Summary}

Hepatic stellate cells play a crucial role in the development of liver fibrosis. In a damaged liver, stellate cells undergo activation, which is manifested as a change of their phenotype: differentiation of stellate cells to myofibroblast-type cells, expression of alpha-Smooth Muscle Actin, their proliferation and a reduction in the size of cytoplasmic lipid droplets. The aim of this study was to determine the number and morphology of stellate cells in the canine liver affected by congenital portosystemic shunt (PSS) and portal vein hypoplasia hepatic microvascular dysplasia (PVH-HMD).

The material for investigation were archived paraffin blocks with liver samples collected supravitally from six dogs with PSS, six dogs with PVH-HMD and six healthy dogs. On the HE-stained sections, the number of stellate cells per 100 hepatocytes was counted (Sztark method) and the diameter of veins in the hepatic triads was measured (light microscope Olympus BX 43, SC30 camera, CellSens Entry 2011 Olympus). In addition, the diameter of lipid droplets in stellate cells was measured (computed image analysis system LUCIA 4.21). The results were analysed statistically (the Kruskal-Wallis test followed by Dunn's post-hoc procedure; significance level $(\alpha)$ at 0.05 ; Statistica 12 StatSoft Inc.). The degree of liver fibrosis was determined (Masson's method of slide stain; Scheuer scale). The liver samples from the dogs with PSS and PVH-HMD were stained immunohistochemically with Monoclonal Mouse Anti-Human Smooth Muscle Actin ( $\alpha-S M A)$, clone 1A4, antibodies (DAKO).

Portosystemic shunt and primary portal vein hypoplasia in the dog results in a reduction in the diameter of portal vein branches and in insufficient portal blood flow through the liver. In the material investigated, this was particularly evident in the animals affected by PSS: such dogs had a significantly smaller diameter of the veins than did the healthy dogs $(p<0.001)$ or the dogs with PVH-HMD $(p=0.023)$. Fibrosis and the expression of $\alpha$-SMA were stronger in the dogs with PSS than in those with PVH-HMD. Moreover, the dogs with PSS had a significantly higher average number of stellate cells than the healthy animals $(p=0.007)$ did. However, the examination of the material revealed an enlargement of cytoplasmic lipid droplets: the dogs with PSS had a significantly larger diameter of lipid vacuoles in the cytoplasm of stellate cells than did the healthy animals $(p<0.001)$ or the dogs with PVH-HMD $(p=0.043)$; the dogs with PVH-HMD had lipid droplets with a significantly larger diameter than the healthy animals $(p<0.001)$ did.

Hypoperfusion of the liver and the accompanying regressive lesions in hepatocytes result mainly in an increased number of stellate cells and stronger expression of $\alpha$-SMA, while cytoplasmic lipid droplets in the stellate cells are not reduced in size. The present study indicates the need for detailed analyses of clinical cases and warrants further comprehensive studies of comparative hepatopathology because it demonstrates differences between humans and dogs in the morphological indicators of hepatic stellate cell activation in chronic liver damage.

Keywords: hepatic stellate cells, dog, portosystemic shunt, portal vein hypoplasia 
The stellate cells, situated in the perisinusoidal spaces in the rat liver, were first described by Karl Wilhelm von Kupffer in 1876 and were initially classified as perivascular connective tissue cells. He later categorized these cells as endothelial cells with phagocytic activity (19). Further research, carried out among others by the Polish pathologist Tadeusz Browicz, helped differentiate between hepatic macrophages (Kupffer-Browicz cells) and stellate cells, a form of pericytes $(11,19)$.

The stellate cells and their role were investigated and elucidated particularly by Toshio Ito (in 1951, with Nemoto), and one of the names of these cells is derived from his surname (11). Throughout the years, numerous scientists have studied stellate cells, so the function of these cells in the liver - and indirectly in the body as a whole - has been gradually explained and detailed.

Hepatic stellate cells, also called Ito cells, perisinusoidal cells or lipid-accumulating cells, constitute $5 \%-8 \%$ of the cellular population in the liver (11). The cytoplasm of stellate cells contains large lipid vacuoles that measure up to $8 \mu \mathrm{m}$ in diameter in humans and occupy approximately $20.5 \%$ of the total cell volume, whereas in the dog they measure from 0.5 to $5 \mu \mathrm{m}$ in diameter $(19,21)$.

Stellate cells have two types of cytoplasmic processes, namely interhepatocellular and subendothelial ones, or the longer and the shorter ones, and these serve to surround the most proximate sinus and the neighbouring ones $(2,11,19)$. In the healthy liver, they store vitamin A $(80 \%-90 \%$ of vitamin A pool in relation to the body mass), metabolize retinoids, modulate the sinusoidal blood flow, synthesize components of the extracellular matrix, synthesize growth factors, cytokines and erythropoietin, and components of the plasminogen-activating system (PAS; 11, 19, 20, 23, $24,26,31)$.

In a damaged liver, stellate cells undergo activation, which is manifested as a change of their phenotype and an increase in the production of collagen, especially type $\mathrm{I}$, of which they are the main source $(1,6,12$, $23,24,31$ ). Activated hepatic stellate cells have been implicated in assisting liver regeneration by producing angiogenic factors, as well as factors that modulate endothelial cell and hepatocyte proliferation and by remodelling the ECM (32). Proliferation and differentiation of stellate cells to myofibroblast-type cells are associated with hepatic fibrosis, while the expression of alpha-Smooth Muscle Actin ( $\alpha$-SMA) is believed to be an activation marker $(6,12,23,24,31)$. Furthermore, during the activation of stellate cells, cytoplasmic lipid droplets are reduced in size, and if they occupy less than $20 \%$ of the cytoplasm volume, Ito cells are considered "transitional" $(11,19,26)$.

Congenital portosystemic shunts are incorrect vascular connections between the portal vein circulation and systemic circulation, which allows the flow of portal blood directly into systemic circulation, bypassing the liver $(18,24)$. Portosystemic shunts are more common in pure-breed dogs than in cross-breed individuals (18). Intrahepatic shunts are generally diagnosed in large dog breeds, such as Doberman, Golden Retriever, Labrador, Irish Setter, Samoyed, Irish Wolfhound and German Shepherd, whereas extrahepatic shunts are diagnosed in small dog breeds, such as Yorkshire Terrier, Miniature Schnauzer, Cairn Terrier, Maltese, Miniature Poodle and Dachshund (27).

Clinical signs of a congenital portosystemic shunt in a dog usually become evident at a young age, less than 12 months, and no sex predilection is seen (25). The signs are varied and depend on the size and location of the shunt (27). Apart from non-specific gastrointestinal signs and delayed growth and development of young dogs, the clinical picture is dominated by hepatic encephalopathy induced by insufficient blood clearance of toxic compounds originating from the digestive system (ammonia, mercaptans, short-chained fatty acids, gamma-aminobutyric acid, endogenous benzodiazepines and others; 18, 25).

Similar clinical signs are seen in dogs with hepatic microvascular dysplasia (HMD; 25). It is a congenital developmental condition of blood vessels that is morphologically recognized only by the histopathological examination of the liver (8). Some researchers categorize it as primary portal vein hypoplasia $(\mathrm{PVH} ; 9,10$, 27). Hypoplasia of the portal vein is most commonly reported in Yorkshire Terriers and Cairn Terriers, as well as in Maltese Dogs, Dachshunds, Poodles, Shih Tzu, Lhasa Apso, Cocker Spaniels, and West Highland White Terriers $(14,18,25)$. The histopathological image reveals hypoplasia of portal vein branches or lack thereof, secondary hyperplasia of arterial blood vessels and hepatocyte atrophy. This is a typical presentation of the reaction to insufficient perfusion through the liver and, as described by Cullen (10), it is indistinguishable from the histopathological image of the congenital portosystemic shunt.

The objective of the study was to determine the number and morphology of stellate cells in the canine liver affected by congenital portosystemic shunt (PSS) and portal vein hypoplasia - hepatic microvascular dysplasia (PVH-HMD).

\section{Material and methods}

The materials investigated were archived paraffin blocks with liver samples collected supravitally from six dogs with congenital portosystemic shunt and from six dogs with primary portal vein hypoplasia. The dogs, aged from six months to four years, represented different breeds and both sexes. The physical examination demonstrated non-specific gastrointestinal signs in all dogs, together with severe hepatic encephalopathy manifestations. The control consisted of liver samples from six clinically healthy dogs aged 2-4 years. The collected material was fixed in $10 \%$ buffered formalin and embedded in paraffin (Paraplast) for examination under a light microscope. Sections of $4-\mu \mathrm{m}$ in thickness were routinely stained with haematoxylin and eosin (HE) and by 
Masson's method for the presence of connective tissue collagen fibres (4).

The histopathological diagnosis was based on the routinely-stained sections and samples stained by histochemical procedures. On the HE-stained sections, the number of stellate cells was determined and counted according to a method proposed by Sztark (11): the number of stellate cells per 100 hepatocytes. In addition, the diameter of lipid droplets in stellate cells was measured with the computed image analysis system LUCIA 4.21. The results were analysed statistically.

The diameter of veins in hepatic triads was measured (this analysis was carried out with a light microscope: Olympus BX 43, coupled with a PC, a SC30 camera and a computed image analysis software: CellSens Entry 2011 Olympus; photographic documentation was recorded simultaneously), and the degree of liver fibrosis was determined according to the Scheuer scale (13) to make the histopathological lesions objective and to determine the degree of hepatic blood flow reduction.
Furthermore, liver samples from the dogs with portosystemic shunt and portal vein hypoplasia were stained immunohistochemically with Monoclonal Mouse Anti-Human Smooth Muscle Actin ( $\alpha$-SMA), clone 1A4, antibodies (DAKO).

Statistical methods. Numerical variables were presented as the median, interquartile range (IQR) and range, and compared between groups by means of the Kruskal-Wallis test followed by the Dunn's post-hoc procedure. The significance level $(\alpha)$ was set at 0.05 . The analysis was performed by the Statistica 12 software (StatSoft Inc.).

\section{Results and discussion}

The histopathological examination of samples collected from the healthy dogs revealed a mild interstitial degeneration of hepatocytes located around the central veins, and lipid vacuoles in single hepatocytes were detected in three dogs. The diameters of veins in hepatic triads are detailed in Table 1 and Figure 3. The aver-

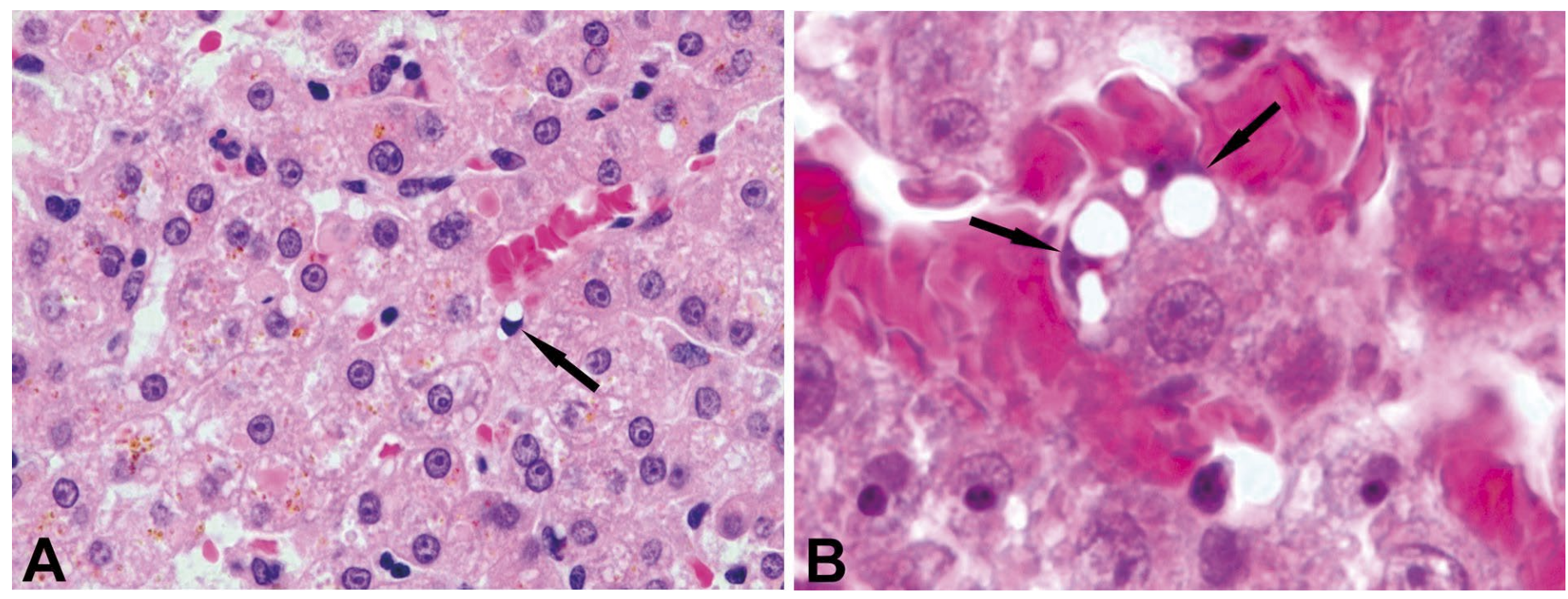

Fig. 1. A - a stellate cell in the perisinusoidal space in the liver of a clinically healthy dog, with regular lipid droplets visible in the cytoplasm (arrow), HE stain., 40× lens; B - stellate cells in the perisinusoidal space in the liver of a dog with a congenital portosystemic shunt (arrows), HE stain., 100 $\times$ lens

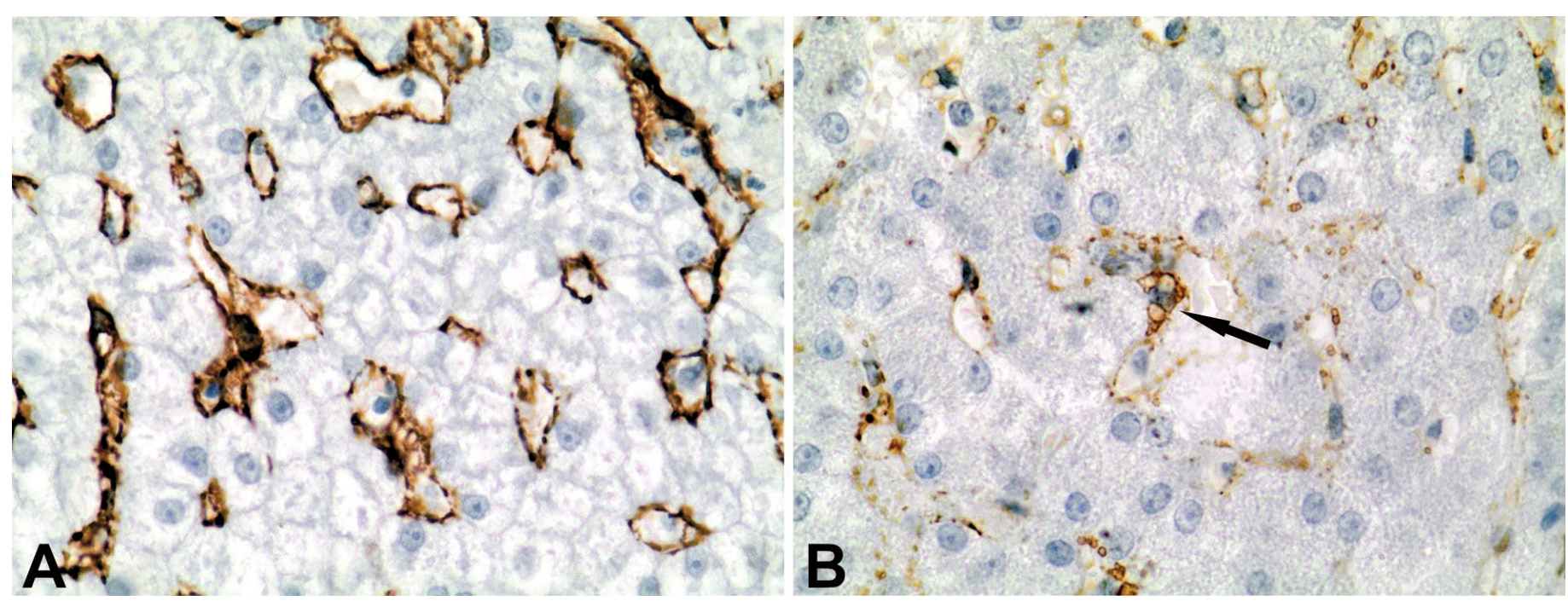

Fig. 2. Immunohistochemical staining: A - strong expression of $\alpha$-SMA (brown colour) in the perisinusoidal spaces in the liver of a dog affected with portosystemic shunt, $40 \times$ lens; B - weak expression of $\alpha$-SMA (light brown colour) in the perisinusoidal spaces in the liver of a dog affected with portal vein hypoplasia. A stellate cell with lipid droplets and actin microfilament expression is visible in the central area of the image (arrow), $40 \times$ lens 
age number of stellate cells per 100 hepatocytes was 5.41 (Tab. 2, Fig. 4). The stellate cells contained 1 to 4 clearly visible lipid droplets in cytoplasm (Fig. 1A). The diameters of lipid vacuoles are presented in Table 3 and Figure 5.

Regressive lesions in hepatocytes (atrophy, interstitial and hydropic degeneration, necrosis) were found in all affected dogs; the lesions were more severe in the dogs with portosystemic shunt, and, in addition, pigment granulomas were detected in two dogs with portosystemic shunts. According to the Scheuer scale, fibrosis was assessed at 1-2 in the patients with portal vein hypoplasia and at 2-3 (more pronounced) in the dogs affected by a portosystemic shunt. The diameters of veins in hepatic triads are given in Table 1 and Figure 3; moreover, a loss of the vein profile in the hepatic triad was observed in one dog with a portosystemic shunt. The dogs affected by portosystemic shunts had a significantly smaller diameter of the veins than the healthy dogs $(p<0.001)$ or the dogs with portal vein hypoplasia $(p=0.023)$. No significant differences were observed between healthy dogs and individuals with portal vein hypoplasia $(\mathrm{p}=0.112)$.

The average number of stellate cells per 100 hepatocytes was 6.06 in the dogs affected by portal vein hypoplasia and 6.83 in the dogs with portosystemic shunt (Tab. 2, Fig. 4). The dogs with portosystemic shunt had a significantly higher average number of stellate cells (Ito cells) than the healthy animals $(p=0.007)$ did. No significant differences were observed between the

Tab. 1. Diameters of veins in portal triads and the degree of liver fibrosis assessed with the Scheuer scale in dogs with portosystemic shunt (PSS) and portal vein hypoplasia (PVH-HMD) compared to healthy dogs

\begin{tabular}{|l|c|c|c|}
\hline \multicolumn{1}{|c|}{ Group } & $\mathrm{n}$ & $\begin{array}{c}\text { Vein diameter }(\mu \mathrm{m}) \\
\text { Median, IQR (range) }\end{array}$ & $\begin{array}{c}\text { Fibrosis-Scheuer scale } \\
\text { (points) }\end{array}$ \\
\hline Healthy & 23 & $82.1,49.9-97.3(37.5-188.8)$ & no fibrosis \\
PVH-HMD & 12 & $36.9,31.2-74.5(22.2-126.9)$ & $1-2$ \\
\hline PSS & 13 & $19.1,15.7-29.8(6.3-42.2)$ & $2-3$ \\
\hline
\end{tabular}

Tab. 2. The average number of stellate cells (Ito cells) per 100 hepatocytes in dogs with portosystemic shunt (PSS) and portal vein hypoplasia (PVH-HMD) compared to healthy dogs

\begin{tabular}{|l|c|c|}
\hline \multicolumn{1}{|c|}{ Group } & n & $\begin{array}{c}\text { Average Ito cells per 100 hepatocytes } \\
\text { Median, IQR (range) }\end{array}$ \\
\hline Healthy & 6 & $5.41,4.80-5.70(4.73-5.79)$ \\
PVH-HMD & 6 & $6.06,5.56-6.37(5.32-6.52)$ \\
\hline PSS & 6 & $6.83,6.45-7.27(5.56-7.84)$ \\
\hline
\end{tabular}

Tab. 3. The diameter of lipid droplets in the cytoplasm of stellate cells (Ito cells) in dogs with portosystemic shunt (PSS) and portal vein hypoplasia (PVH-HMD) compared to healthy dogs

\begin{tabular}{|l|r|c|}
\hline \multicolumn{1}{|c|}{ Group } & $\mathrm{n}$ & $\begin{array}{c}\text { Lipid droplet diameter }(\mu \mathrm{m}) \\
\text { Median, IQR (range) }\end{array}$ \\
\hline Healthy & 50 & $2.52,1.76-2.52(1.45-3.58)$ \\
PVH-HMD & 50 & $4.40,3.64-4.40(2.85-6.30)$ \\
PSS & 100 & $4.40,4.02-5.63(2.85-10.77)$ \\
\hline
\end{tabular}

dogs with portal vein hypoplasia and the animals with portosystemic shunt $(p=0.390)$ or between dogs with portal vein hypoplasia and healthy dogs $(\mathrm{p}=0.390)$.

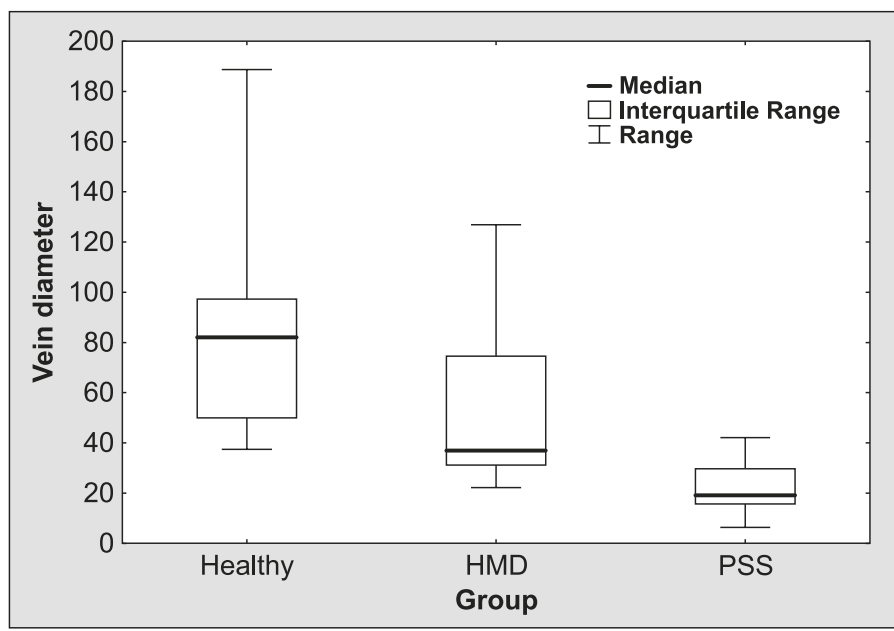

Fig. 3. Diameters of the veins in the portal triads in the dogs with portosystemic shunt (PSS) and portal vein hypoplasia (PVH-HMD) compare to healthy dogs

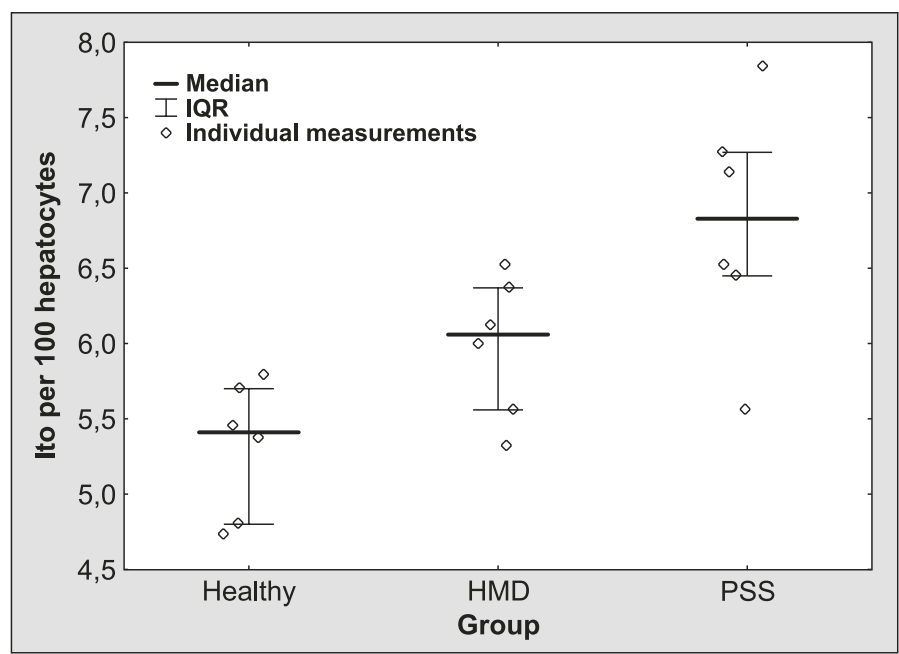

Fig. 4. An average number of stellate cells (Ito cells) per 100 hepatocytes in the dogs with portosystemic shunt (PSS) and portal vein hypoplasia (PVH-HMD) compare to healthy dogs

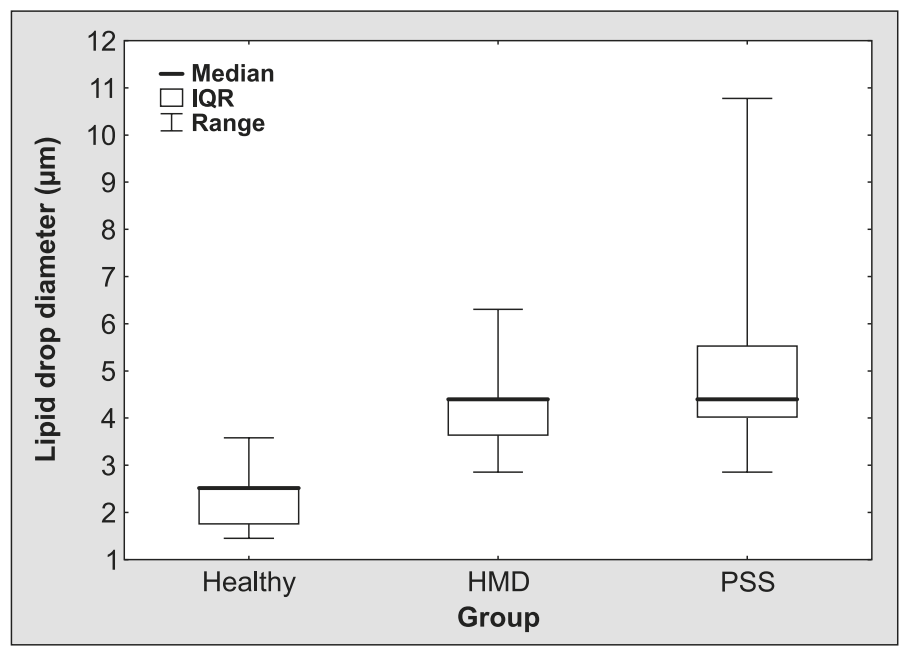

Fig. 5. The diameter of lipid droplets in the cytoplasm of stellate cells (Ito cells) in the dogs with portosystemic shunt (PSS) and portal vein hypoplasia (PVH-HMD) compare to healthy dogs 
Stellate cells contained 1 or 2 evident lipid droplets in cytoplasm (Fig. 1B); the diameters of lipid vacuoles in particular treatment groups are detailed in Table 3 and Figure 5 . The dogs affected by portosystemic shunt had a significantly larger diameter of lipid vacuoles in the cytoplasm of stellate cells than did the healthy animals $(\mathrm{p}<0.001)$ or the dogs with portal vein hypoplasia $(p=0.043)$. The dogs affected by portal vein hypoplasia had lipid droplets with a significantly larger diameter than the healthy animals $(\mathrm{p}<0.001)$ did.

The examination of the immunohistochemically stained sections demonstrated that the expression of alpha-Smooth Muscle Actin ( $\alpha$-SMA) was visible in the perisinusoidal space and near the portal space in all diseased dogs. On most sections $(5 / 6)$ from the dogs with a portosystemic shunt, the expression of $\alpha$-SMA was very strong (Fig. 2A), while it was weaker in the six dogs with portal vein hypoplasia and very weak in two of these dogs (Fig. 2B).

Portosystemic shunt or primary portal vein hypoplasia in the dog results in lesions of the intrahepatic vascular system, such as a reduction in the diameter of portal vein branches or a lack thereof and secondary hyperplasia of arterial blood vessels - this is a histopathological sequence of insufficient portal blood flow through the liver (9). Furthermore, regressive lesions in hepatocytes are reported, such as hepatocyte atrophy, interstitial or hydropic degeneration or even necrosis. Observations made in this study are consistent with the literature data $(3,10)$. The lesions are chronic and may be accompanied by hepatic fibrosis, which, according to the literature, occurs mainly in cases of primary portal vein hypoplasia $(8,9,31)$. In our study, regressive lesions, both degenerative lesions and hepatocyte necrosis, were more pronounced in sections from the dogs affected by a portosystemic shunt. In addition, developing pigment granulomas, located in the liver and occurring together with progressive hepatocyte turnover, were found in two dogs (10).

A reduction in the diameter of the vein in portal triads is one of the morphological indicators of vascular lesions (8-10). In the material investigated, this was particularly evident in the animals affected by portosystemic shunt (the differences in vascular diameters in relation to the healthy animals were statistically significant). The flow of portal blood through the liver was thus substantially reduced in the dogs with portosystemic shunt in comparison with the healthy animals, which resulted not only in more severe hepatic fibrosis in the periportal area, but also in the bridging fibrosis and effacement of the hepatic lobular architecture, as seen in the dogs affected by portosystemic shunt. In the dogs with portal vein hypoplasia, fibrosis was located mainly in periportal zones or extended slightly beyond these areas, but without any disruption of the lobule structure. The marked histopathological lesions observed in both groups, but especially severe in the dogs with portosystemic shunt, justify the thesis, found in other papers, that clinical signs usually develop earlier and are more severe in dogs with portosystemic shunt than in dogs with portal vein hypoplasia $(8,18)$.

Stellate cells play a very important role in the development of fibrotic lesions in the liver and in the resulting lesions produced by insufficient portal blood flow through the liver, which leads to the lack or deficiency of factors supplied by the liver (such as insulin, glucagon, epithelial growth factor; 10) and progressive organ damage. Therefore an increased number of stellate cells were found in liver specimens from the diseased dogs in comparison with liver samples from the healthy animals. An increase in the number of stellate cells is one of the markers indicating the activation of these cells $(16,19$, 31 ). The results of the present study are consistent with observations made by Carpino et al. (6) in humans and by Aleksic-Kovacevic et al. (1) in in cats with hepatic fibrosis, in which a correlation between hepatic fibrosis and stellate cell activation was reported.

Moreover, Aleksic-Kovacevic et al. (1) demonstrated that the intensity of $\alpha$-SMA expression in hepatic stellate cells was correlated with the degree of hepatic fibrosis. This relation was also evident in the current study. In the dogs affected by a portosystemic shunt, with marked vascular lesions and the resulting significant hypoperfusion and severe histopathological lesions in the liver, the expression of $\alpha$-SMA was stronger than in the dogs with portal vein hypoplasia.

A reduction in the size of cytoplasmic lipid droplets is another signal of stellate cell activation $(19,31)$. Morphological changes in stellate cells were reported in studies on dogs with dexamethasone-induced hepatopathy (29) and acute hepatocyte damage. These were manifested as a statistically significant reduction in the size of cytoplasmic lipid droplets as early as day 5 after the administration of the first dose of this medication. However, the examination of the material revealed an enlargement of cytoplasmic lipid droplets in stellate cells in liver samples both from the dogs with portosystemic shunt and from those affected by portal vein hypoplasia.

The increase in the diameter of cytoplasmic lipid droplets may result from an increased input of vitamin $A$ in the diet $(15,22)$, as this vitamin, when administered in excessive amounts, produces such lesions in stellate cells. The assumption in the current study that the enlargement of cytoplasmic lipid droplets in the stellate cells of the liver in the diseased dogs resulted from an excess of vitamin $\mathrm{A}$ in the diet is impossible to verify, as the study was conducted on archive samples. The clinical history of the healthy dogs (control group) reveals that their diet was well-balanced, also in terms of vitamins.

However, if one assumed that all dogs had been fed a well-balanced diet, then the results of this study would suggest that the activation of stellate cells in the case of chronic liver damage in dogs takes a slightly different pathway than it does in humans or rodents and also 
different from the one in dogs with acute liver damage $(11,29)$, since it presents mainly with an increase in the number of stellate cells and a pronounced expression of $\alpha$-SMA. Schotanus et al. (28) suggest that there is a substantial similarity between the reactions of stellate cells to liver damage in humans and dogs, whereas the present study demonstrates differences in the morphological indicators of activation in chronic liver damage. It is unknown whether these differences result from a poorly balanced diet, a change in the retinoid metabolism or insufficient portal blood flow through the organ.

Previous studies by Ijzer et al. (17) partly explain the species differences in how the reaction to liver damage takes place, as they indicate that $\alpha$-SMA is also expressed in the liver of healthy dogs, whereas it is usually absent in humans with a healthy liver $(6,11)$. Ijzer et al. (17) suggest that $\alpha$-SMA expression in the dog results from the need for a more active regulation of blood sinusoidal flow through this organ compared to other species.

The interpretation of the differences in $\alpha$-SMA expression proposed by Ijzer et al. (17) raises the question of whether the increase in the number of stellate cells and stronger $\alpha$-SMA expression, seen in the case of insufficient portal blood flow through the liver (which is especially limited in portosystemic shunts), represents the activation of these cells or is simply a manifestation of the liver's adaptation to inadequate (abnormal) vascularization.

Marked hepatic fibrosis is a consequence of hypoperfusion, being directly proportional to the reduction in the diameter of portal vein branches and, as a result, to the degree of limitation in the portal blood flow through the liver. Hypoperfusion of the liver and the accompanying regressive lesions in hepatocytes result mainly in an increased number of stellate cells and a stronger expression of $\alpha$-SMA, while cytoplasmic lipid droplets in stellate cells are not reduced in size. The present study indicates the need for detailed analyses of clinical cases and warrants further comprehensive studies of comparative hepatopathology.

\section{References}

1. Aleksic-Kovacevic S., Kukolj V., Kureljusic B., Marinkovic D., Knezevic D., Ignjatovic I., Jovanovic M., Knezevic M., Gledic D.: Role of hepatic stellate cells (HSCs) in the development of hepatic fibrosis in cats with polycystic kidney disease (PKD). Acta Vet. Beograd 2010, 60, 391-400.

2. Atzori L., Poli G., Perra A.: Hepatic stellate cells: a star cell in the liver. Int. J. Biochem. Cell Biol. 2009, 41, 1639-1642.

3. Baade S., Auperle H., Grevel V., Schoon H. A.: Histopatological and immunohistochemical investigations of hepatic lesions associated with congenital portosystemic shunts in dogs. J. Comp. Pathol. 2006, 134, 80-90.

4. Bancroft J. D., Cook H. C.: Manual of Histological Techniques and their Diagnostic Application. Churchill Livingstone, Edinburgh, London, Madrid, Melbourne, New York, Tokyo 2000.

5. Budny T., Palmers D., Stratman U., Minin E., Herbst H., Spiegel H. U.: Morphologic features in the regenerating liver - a comparative intravital, light microscopical and ultrastructural analysis with focus on hepatic stellate cells. Virchows Arch. 2007, 451, 781-791.

6. Carpino G., Franchito A., Morini S., Corradini S. G., Merli M., Gaudio E.: Activated hepatic stellate cells in liver cirrhosis. A morphologic and morphometrical study. Ital. J. Anat. Embryol. 2004, 109, 225-238.
7. Chong-Yang Z., Wei-Gang Y., Pei H., Jia-Hui L., Chun-Xu W.: Liver fibrosis and hepatic stellate cells: etiology, pathological hallmarks and therapeutic targets. World J. Gastroenterol. 2016, 22, 10512-10522.

8. Christiansen J. S., Hottinger H. A., Allen L., Philips L., Aronson L. R.: Hepatic microvascular dysplasia in dogs: a retrospective study of 24 cases (1987-1995). J. Am. Anim. Hosp. Assoc. 2000, 36, 385-389.

9. Cullen J. M., Ingh T. S. G. A. M. van den, Bunch S. E., Rothuizen J., Washabau R. J., Desmet V. J.: Morphological classification of circulatory disorders of the canine and feline liver, [in:] WSAVA Liver Standardization Group: WSAVA Standards for clinical and histological diagnosis of canine and feline liver diseases. Saunders Elsevier, Spain 2006, 41-59.

10. Cullen M. J., Stalker M. J.: Hepatocellular adaptations and intracellular accumulation, [in:] Maxie G. M. (ed.): Jubb, Kennedy and Palmer's pathology of domestic animals, $6^{\text {th }}$ edition. ELSEVIER Incorporation, St. Louis, Missouri 2016, p. 269-278

11. Flisiak R.: Role of Ito cells in the liver function. Pol. J. Pathol. 1997, 48, 139-145 .

12. Friedman S. L.: Molecular regulation of hepatic fibrosis; an integrated cellular response to tissue injury. J. Biol. Chem. 2000, 275, 2247-2250.

13. Gabriel A., Mietkiewski J., Ziółkowski A.: Aktualna klasyfikacja morfologiczna przewlekłych zapaleń wątroby: zalety i wady. Pol. J. Pathol. 1999, 50, 5-11.

14. Gough A., Thomas A.: Breed Predispositions to Disease in Dogs and Cats. SIMA WLW, Warszawa 2006.

15. Guerra J. M., Daniel A. G., Aloia T. P., de Sigueira A., Fukushima A. R., Simoes D. M., Reche-Juior A., Cogliati B.: Hypervitaminosis A-induced hepatic fibrosis in cats. J. Feline Med. Surg. 2014, 16, 243-248.

16. Hellerbrand C.: Hepatic stellate cells - the pericytes of the liver. Pfluges Arch. 2013, 465, 775-778.

17. Ijzer J., Roskams T., Molenbeek R. F., Ultee T., Penning L. C., Rothuizen J., van den Ingh T. S.: Morphological characterization of portal myofibroblasts and hepatic stellate cells in the normal dog liver. Comp. Hepatol. 2006, 16, 7.

18. Johnson S. E.: Chronic hepatic disorders, [in:] Ettinger S. J., Feldman E. C. (ed.): Textbook of Veterinary Internal Medicine. vol. 2, 5th ed., Section XI, Chapter 143, W. B. Saunders Company, Philadelphia 2000, p. 1298-1325.

19. Kmieć $Z$.: The role of hepatic stellate cells in the regulation of the liver functions II. Cooperation with other cell types in the development of liver fibrosis. Adv. Cell Biol. 2002, 30, 61-74.

20. Knittel T., Kobold D., Saile B., Grundmann A., Neubauer K., Piscaglia F., Ramadori $G$.: Rat liver myofibroblasts and hepatic stellate cells: different cell populations of the fibroblast lineage with fibrogenic potential. Gastroenterology 1999, 117, 1205-1221.

21. Kobayashi K., Sakata K., Miyata K., Iino T., Iwasaki S., Takahashi K.: Mast cell-Ito cell pairings found in the Disse's spaces in the liver of the Beagle dog. Arch. Histol. Jpn. 1985, 48, 483-496.

22. Levine P. H. L., Delgado Y., Theise N. D., West A. B.: Stellate-cell lipidosis in liver biopsy specimens. Recognition and significance. Am. J. Clin. Pathol. 2003, $119,254-258$.

23. $L i$ D., Friedman $S$. L.: Liver fibrogenesis and the role of hepatic stellate cells: new insights and prospects for therapy. J. Gastroenterol. 1999, 14, 618-633.

24. Li D., Kim J. H.: The role of activated hepatic stellate cells in liver fibrosis, portal hypertension and cancer angiogenesis. Korean J. Hepatol. 2007, 13, 309-319.

25. Nelson R. W., Couto C. G.: Choroby wątroby i dróg żółciowych psów, [in:] Lechowski R., Schollenberger A., Pomianowski A. (ed.): Choroby wewnętrzne małych zwierząt. Polish edition, Publishing House Galaktyka, Łódź 2008, p. 373-387.

26. Plewka K., Szuster-Ciesielska A., Kandefer-Szerszeń M.: Role of stellate cells in alcoholic liver fibrosis. Postepy Hig. Med. Dośw. 2009, 63, 303-317.

27. Richter K. P.: Diseases of the liver and hepatobilliary system, [in:] Tams T. R. (ed.): Handbook of Small Animal Gastroenterology, $2^{\text {nd }}$ edition, Chapter 9. Saunders, USA 2003, p. 286-352.

28. Schotanus B. A., van den Ingh T. S., Penning L. C., Rothuizen J., Roskams T. A., Spee B.: Cross-species immunohistochemical investigation of the activation of the liver progenitor cell niche in different types of liver disease. Liver Int. 2009, 29, 1241-1252.

29. Sobczak-Filipiak M., Szarek J., Czopowicz M., Mieczkowska J., Lechowski R. Hepatic stellate cells in the liver in dogs with steroid-induced hepatopathy. Bull. Vet. Inst. Puławy 2014, 58, 272-276.

30. Stalker M. J., Hayes M. A.: Liver and biliary system, [in:] Maxie M. G. (ed.): Jubb, Kennedy and Palmer's Pathology of Domestic Animals. $5^{\text {th }}$ edition, vol. 2. Saunders Ltd., China 2007, p. 297-388.

31. Takuma T., Friedmann S. L.: Mechanisms of hepatic stellate cell activation. Nat Rev. Gastro. Hepat. 2017, 14, 397-411.

32. Yin C., Evason K. J., Asahina K., Stainier D. Y. R.: Hepatic stellate cells in liver development, regeneration, and cancer. J. Clin. Invest. 2013, 123, 1902-1910.

Corresponding author: Małgorzata Sobczak-Filipiak DVM, PhD, Nowoursynowska 159C, 02-776 Warsaw, Poland; e-mail: malgorzata sobczak filipiak@sggw.pl 